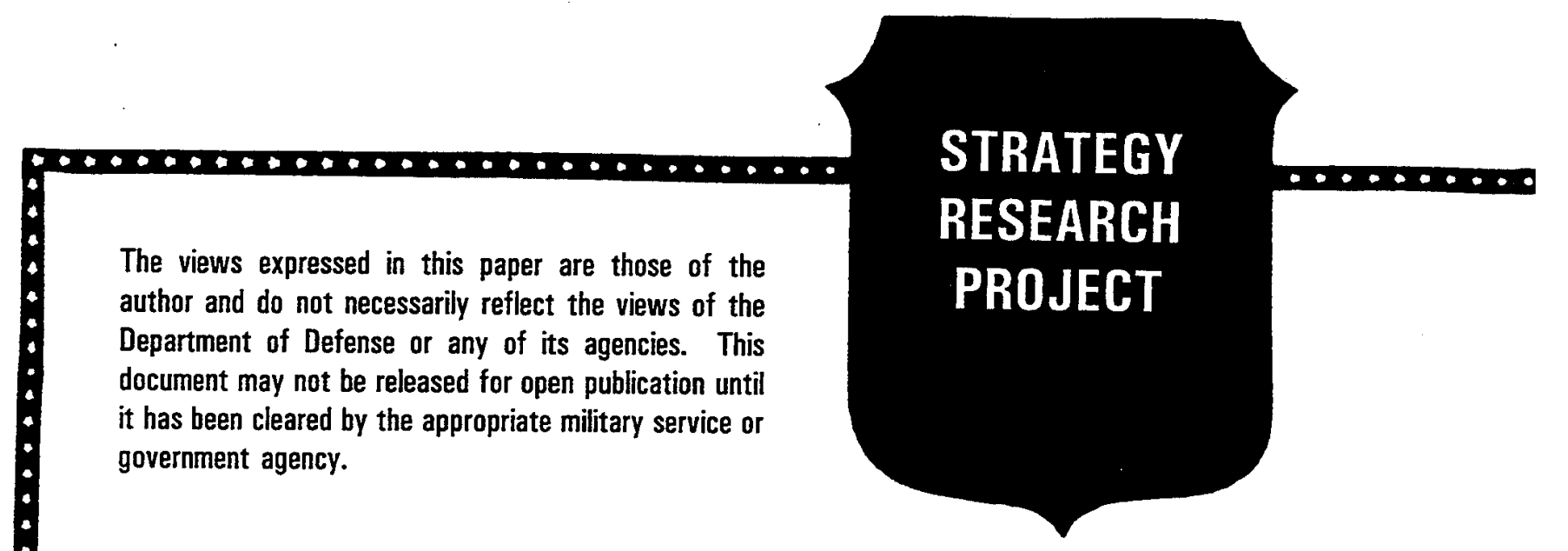

\title{
THE EFFECTS OPERATIONS OTHER THAN WAR HAS ON THE READINESS OF THE UNITED STATES ARMY
}

\author{
BY \\ LIEUTENANT COLONEL JERRY D. HATLEY \\ United States Army
}

DISTRIBUTION STATEMENT A:

Approved for public release.

Distribution is unlimited

\section{2}

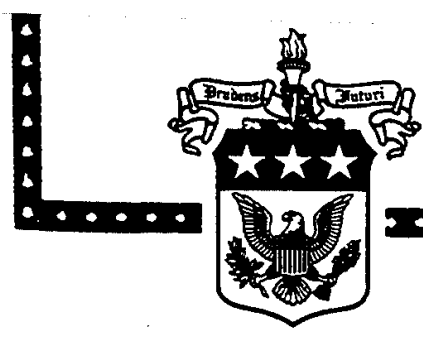

USAWC CLASS OF 1996

U.S. ARMY WAR COLLEGE, CARLISLE BARRACKS, PA 17013-5050 


\section{USAWC STRATEGY RESEARCH PROJECT}

The views expressed in this paper are those of the author and do not necessarily reflect the views of the Department of Defense or any of its agencies. This document may not be released for open publication until it has been cleared by the appropriate military service or government agency.

THE EFFECTS OPERATIONS OTHER THAN WAR HAS ON THE READINESS OF THE UNITED STATES ARMY

by

Lieutenant Colonel Jerry D. Hatley United States Army

Colonel Sandy Mangold

Project Adviser

DISTRIBUTION STATEMENT A: Approved for public release. Distribution is unlimited.

U.S. Army War College

Carlisle Barracks, Pennsylvania 17013 


\section{ABSTRACT}

AUTHOR: Jerry D. Hatley (LTC), USA

TITLE: The effects Operations Other Than war has on the readiness of the United States Army

FORMAT: Strategy Research Project

DATE: 15 April 1966 PAGES: 22 CLASSIFICATION: Unclassified

The United States Army is committed to Operations Other Than War to protect the strategic interests of the United States. With the recent increase in the number of peacekeeping missions a concern exists on the negative effects OOTW has on the Readiness of the Army. If the Army is focused on peacekeeping, will it be trained and ready to fight a major regional conflict without extensive retraining? This paper presents a view that indicates there is some confusion on exactly what role OOTW has in this nation's National Strategic Policy and it will address the positive and negative viewpoints of the effects OOTW has on the readiness of the United States Army. A summation will provide an analysis of the different viewpoints. 


\section{ISSUES CONCERNING OOTW AND READINESS}

On the day of battle, soldiers and units will fight as well or as poorly as they are trained. Training to high standards is essential in both peace and war. Never can Army forces afford not to train and maintain the highest levels of readiness. Every commander, every soldier, every unit in a force-projection army must be trained and ready to deploy and fight. Leaders have the responsibility to train subordinates. This may be their most solemn responsibility. ${ }^{1}$

The founding fathers created a standing army for the sole purpose of protecting and defending this country against an adversary who threatens the security of the United states of America. Based on past history, the chances are very good that this country will become involved in another major conflict. The principal questions are: when will it happen? where will the conflict take place? and will the Army be trained and ready?

Today, as the United States Army becomes increasingly involved in Operations other Than war (OOTW) there is a legitimate concern on the effects 0OTW has on the Army's readiness and its ability to quickly respond and fight a Major Regional Conflict (MRC). The Army is being increasingly stretched to its limits as it responds to numerous ooTw requirements. This becomes even more critical because of the recent downsizing in which numerous units and thousands of personnel were virtually eliminated from the force structure.

The debate on the effects of OOTW on Army readiness is not one-sided. One viewpoint is that OOTw does contribute to the 
readiness of the Army because soldiers are conducting numerous tasks that they would normally perform during a war environment. operating in an OOTW environment is the best training the Army can receive as it prepares for a wartime mission. In fact, many of the warfighting requirements on a units Mission Essential Task List (METL) would be trained in an OOTW environment.

The opposing view is that the readiness posture of the United States Army is steadily declining as it becomes immersed in OOTW missions. The Army of today is scattered throughout the world as it becomes increasingly over-committed to OOTW. A concern is that the Army will lose the critical skills to function as an effective combat force. Over a period of time, OOTW operations drains the proficiency away from a highly trained and ready combat force by restricting its ability to conduct frequent and repetitious training in order to maintain the highest level of readiness. Because OOTW requires the soldier to perform as a peacekeeper he will eventually lose that mental toughness which is vital to winning on the battlefield.

The views for both sides provide reasonable arguments on the positive or negative effects 00TW has on the readiness of the U.S. Army. There seems to be considerably differences among military leaders, politicians and academians as they articulate the purposes 0OTW has in the formulation of national strategic policies and the role military forces will perform in this process. The next chapter will focus on the different views military and political leaders have on OOTW and how they perceive 
the role of the military in implementing the policies of the National Command Authority. Subsequent chapters will focus on the positive and negative aspects of OOTW and its effect on the readiness of the United States Army.

\section{THE UNITED STATES ARMY IS COMMITTED TO OOTW}

The Commander-in-Chief committed the United States Army to a future of OOTW as stated in his National strategic security Policy Guidance of 1995:

When our interests call for it, the United States must be prepared to participate in multilateral efforts to resolve regional conflicts and bolster new democratic governments. Thus, our forces must be ready to participate in peacekeeping, peace enforcement and other operations in support of these objectives. ${ }^{2}$

When the members of the National Command Authority (NCA) decide to involve the military in peacekeeping operations they are more attuned to the unique capabilities of the armed forces rather than its combat power. Although, the NCA feels the military is not always the best tool to address humanitarian concerns, nevertheless, under certain conditions, (these conditions are becoming too frequent) the NCA feels use of the armed forces may be appropriate. ${ }^{3}$

Since the concepts of OOTW has yet to be clearly defined, it may be useful to consider a comprehensive list of relevant oOTW activities. They include: nation-building, security assistance, counterinsurgency, punitive strikes, preemptive strikes, sanction or embargo enforcement, counter-terrorism, support to law 
enforcement, disaster relief, humanitarian assistance,

peacekeeping, peace-enforcement, noncombatant evacuation, combat search and rescue and personnel recovery. They span a wide range of operational environments. Some will occur under wholly peaceful circumstances. Others will start that way but evolve into armed confrontation. Others will take place under hostile conditions from the start. Unlike conventional wars, many such operations pose situations in which the rules of engagement are either ambiguous or highly restrictive. ${ }^{4}$

When the Soviet Union dissolved in 1989 the focus of American policy changed dramatically by becoming more global, requiring a far wider range of roles for the Army. As former President Bush described in his "New world Order", he envisioned the United States becoming more involved in promoting stability and security in and among developing nations rather than fighting wars. This required the Army to expand its capabilities from conventional battlefield warfighting to include operations in low intensity conflict environments. To survive in a world of peacekeeping, U.S. soldiers have become more attuended to the dimensions of low intensity conflict, the sensitive political environment, civil military relations, and respect for human rights. Soldiers must now become more involved in peacemaking environment as advisors, instructors, and less as combatants. These changes will require the army to conduct a doctrinal overhaul by changing the focus of doctrine from the conventional battlefield to emphasizing increased flexibility across all 
operational environments. ${ }^{5}$

Since the United States is now the sole "Superpower", some congressional leaders have articulated their views on how to best use the military in an OOTW world. Senator Sam Nunn, a member of the Congressional Armed Services Committee envisions the Army in a new role. He has been an active participant in promoting a change of direction for the U.S. Army from a war fighter to a peacekeeper of domestic issues. Senator Nunn offered a proposal for the fiscal year 1993 National Defense Authorization Act which would have authorized the armed forces to engage in appropriate community service programs in the United States. He feels the armed forces should have a priority of attacking this country's problems first before our precious time and resources are wasted on resolving issues in foreign countries.

We are now leaving a security era that demanded large numbers of U.S. combat forces stationed overseas or operating in forward locations at high states of combat readiness in order to confront a large and quantitatively superior opponent. That era has ended. We are entering a security era that permits a shift in our overall strategy more toward smaller force levels, with fewer overseas deployment and lower operating tempos. It will have to be just as professional - and even more flexible. There will be a much greater opportunity, and we should take advantage of that, than in the past to use military assets and training to assist civilian efforts in critical domestic needs. 6

Senator Nunn feels the American people have made an enormous investment in developing the skills, capabilities, and resources of the Armed Forces. These resources, can make a useful contribution to addressing the serious domestic needs of the United States. There must be a structured program to enable 
community organizations to benefit from the capabilities and qualities of military role models. Senator Nunn feels the military would be a tremendous resource as an example to tens of thousands of inner city and rural youth who, for example, many never had a father in their own home. Instead of putting our resources to work overseas, we have desperate people in America who today need the capabilities of the armed forces.'

A false sense of security prevails by many in this country in believing that over the next ten years, the chance of major American involvement in sustained land warfare in the world will drop to near zero. They feel that the most likely opponents will be gray area organizations, primal militaias, warlord armies, and for the short term, unstable "backlash states". Therefore, the United States forces should undergo substantial strategic disengagement. When the United States finds it necessary to be committed to peacekeeping operations, the military can only be effective if it has undertaken a radical restructuring. This includes not only reorganization and changed emphasis within the armed forces, but also alteration of the fundamental relationship of the U.S. military and the nonmilitary elements of our security and intelligence forces. ${ }^{8}$

To keep up with the fast changing world of DoTw the Army has been rewriting its doctrine to provide clearer guidance on how units and soldiers should perform their missions in an OOTW environment. More emphasis is being given to ooTw than ever. FM 100-5 acknowledges the critical role of OOTW while 
insuring the primary role is warfighting: Operations other than war are not new to the Army. Their pace, frequency, and variety, however, have quickened in the last three decades. The primary focus of the Army is warfighting, yet the Army's frequent role in operations other than war is critical to the security of the United States. Overall, the Army's primary focus is to fight and win the nation's wars. ${ }^{9}$ FM 100-23 says peace operations require a significant change in orientation for military personnel. OOTW requires the entire chain of command to must develop a different mind set than that required for fighting wars. Nevertheless, the force must always be prepared to protect itself and conduct combat operations. ${ }^{10}$

DOTW AS A POSITIVE FACTOR ON ARMY READINESS

It may be OOTW from a distance, but for the soldiers on the ground it looks and feels like war. It may be OOTW looking back, but in the present tense and looking forward, it looks like war. ${ }^{11}$

There are many military leaders who feel OOTW maintains unit readiness. One of the chief proponents of OOTW is Major General David Meade (Retired), who commanded the 10th Mountain Division when it deployed to Haiti:

Because the Haiti operation fell somewhere along the dividing line between wartime operations and peacetime operations, there is a very high correlation between what our soldiers did in Haiti and their wartime mission essential tasks. Therefore, Haiti was excellent training and excellent for readiness. 
Overall, the 10th Mountain Division's readiness improved. We really believe that our training status improved due to our participation in the Haiti operation. Our soldiers conducted combat operations on a daily basis, our staff planned every day, and our leaders gained great experience. Some parts of the Division were even better than we expect to be when we come out of the Joint Readiness Training Center (JRTC) or the Battle Command Training Program (BCTP). 12

General George Joulwan is convinced the U.S. Army should be involved in OOTW operations. When he was the SOUTHCOM commander, General Joulwan felt his organization's participation in OOTW operations was vital to the United States succesful program in South America:

Some have said things are not as they used to be. They never are. It is a changed world from the one we knew only five years ago, and U.S. military organizations and missions must change as well. In fact, one might say that the US military is returning to normal at the conclusion of the Cold War era because, historically, "normal" operations for US Forces are operations other than war. While US military forces must remain ready to fight and win if required, we must now secure and reinforce the peace that has followed the end of the cold war. ${ }^{13}$

Experts working with the United Nations in the area of peacekeeping feel it would be extremely unusual for a well trained unit to lose its warfighting capabilities completely from a short term deployment in a peace operation. In fact, many of the skills needed for combat are exercised and refined during peace operations: communications, logistics, patrolling, self protection, field sanitation and field living are all examples. Besides these specific skills, individuals gain a more mature outlook from deployment in peace operations. Combat units will 
need a little refresher training as part of the normal training cycle, but not a lot, before getting back to their previous level of aggressiveness. The refresher training needed for infantry units is probably live fire exercises and coordinated assault exercises. Other units, including logistical, transportation, and engineering units, will probably return from peace missions better trained to conduct their wartime mission. ${ }^{14}$

Today's American military is more than capable of performing both traditional and non-traditional missions and maintaining the same readiness level. In fact, our armed forces should be re-engineered for the post cold war era. The Army must grow into a highly flexible, lethal, and economical organization, capable of performing more than combat operations in defense of cur national security. As we evolve beyond the cold war, military issues will become less important while international economic competition and stability more important. ${ }^{15}$

The American people have always expected a solid return on their taxpayer investment. Today's Army can perform its basic mission of warfighting, but it also has the technology, skill, and training - the core competencies in engineering, medicine, logistics, planning, intelligence, and communication - to do much more. From humanitarian assistance and disaster relief to peacekeeping, peace-promoting and peace enforcement missions, these non-traditional missions are here today and will continue in the future. The question of to do or not to do is irrelevant. The need is there, the Army has performed these type of missions 
since the early days of the republic, and they alone have the resources to complete the job effectively. Rather than diminish operational capabilities, engagement in non-traditional missions enhances military effectiveness. While the battlefield may be absent, a capability used in a non-traditional setting of OOTW will be honed and strengthened for future employment. ${ }^{16}$

\section{OOTW AS A NEGATIVE FACTOR ON ARMY READINESS}

\section{"Peacekeeping is not a job for soldiers, but only a soldier can do it." Former UN Secretary-General Dag Hammerskold ${ }^{17}$}

To date the military's record in peacekeeping, peacemaking, peace-enforcement and peacebuilding has been a failure. It has failed for a number of reasons, foremost of which are:

(a) Lack of peacemaking experience within the context of the situation.

(b) Lack of clearly articulated criteria.

(c) Absence of a national strategy.

These factors strongly suggest that committing the U.S. military to such operations at this time will limit the effectiveness of the military as a fighting force. ${ }^{18}$

Non-traditional missions are distractions better left to nonmilitary agencies and organizations; at worst, they threaten to diminish combat effectiveness and thrust the military into dangerously political realms. Loading novel responsibilities 
onto the back of the Army could have the perverse effect of diverting focus and resources from the military's central mission of combat training and warfighting. Non-traditional missions could form the core of a new organizational vision for the Army as the nation's general military servant. The arguments against non-traditional military missions can be grouped into three broad categories;

1. They will erode combat effectiveness

2. They are better performed by civilian organizations

3. They will lead to a dangerous level of military involvement in civilian affairs.

The Army's ability to wage war will be in jeopardy if it continues to conduct peacekeeping missions. ${ }^{19}$

A group of vocal senior leaders in our country express the opinion that the Army will lose its warfighting spirit if it engages in "non-fighting" operations. One of these individuals, Mr. Seth Cropsey, former Deputy Undersecretary of the Navy, argues that the U.S. must maintain armed forces whose mission is single mindedly traditional if it expects to act decisively in response to regional threats to U.S. interests. He warns, "humanitarian tasks" are likely to confuse the military about its first responsibility. Nothing good will come of a military as bewildered about its purpose to the nation it is supposed to defend. Senior officers and defense officials also argue passionately that time spent on community service is time not spent training for war because it would detract from the primary 
mission of going to war. ${ }^{20}$

other political leaders such as Representative Norm Dicks (D-WA) voiced his concern on readiness when he said,

\begin{abstract}
"Increasingly, US lawmakers and senior military officials are raising red flags over the unseen toll that UN peacekeeping operations exact from overall US military readiness."
\end{abstract}

Peacekeeping, peacemaking, peace enforcement, and other peacetime contingency operations have increased almost geometrically since the Cold War ended. They inevitably impinge on the ability of the military to carry out the National Military Strategy, which calls for the armed forces to be trained to win two MRC's almost simultaneously. The Presidents Bottom-Up Review failed to take into account the implications of peacekeeping that call into question the capability of the armed forces, particularly the Army, to respond quickly to one Major Regional contingency, much less two.

Congressman Ike Skelton (D-MO), and former Assistant Secretary of Defense Warner, said that the Pentagon would have to withdraw active-duty forces from peacekeeping operations if the need arose to fight in two nearly simultaneous regional conflicts, causing tremendous strains on our resources and soldiers. ${ }^{21}$

Combat units, trained to a fine edge to perform combat missions, cannot help but have that edge degraded when tasked to perform missions that support promoting democracy and stability. Military organizations are formed for purposes other than 
peacekeeping and those original purposes are not served while a nation's military units are deployed and engaged in peacekeeping tasks. Combat skills are degraded because the unit does not train as a total force. It can be argued that the low-level nature of peace operations and the potential for long periods of inactivity support the assertion that combat readiness is degraded over time. ${ }^{22}$

The military's hierarchical structure - with its severe expectations of obedience and its oft-criticized redundancy exists because it is essential to fighting an enemy and defeating him. Ironically it is also what allows the military to perform less demanding, "humanitarian", tasks so readily. But such tasks are likely to confuse the military, about its first responsibility. They would impair its ability to fight and diminish its secondary usefulness as a provider of relief. ${ }^{23}$

Financially The United States Army is paying a price for its participation in OOTw. The funds used for these missions is coming out of the fiscal monies allocated for the year which has a tremendous impact on training. Since a number of peacekeeping operations were undertaken toward the end of fiscal year 94 , the Army found itself in a cash-flow crisis. It had no supplemental appropriations immediately available and no effective line of credit against which to borrow to tide it over. The only "loan window" available was the readiness funding allocated for forces that were not engaged in peacekeeping at that time. Thus, supporting our engaged forces meant making up the cash-flow 
deficit by cutting training, maintenance and supplies (key components of readiness) for some of the non-deployed forces. The Army directed reduced training for three heavy reinforcing divisions. The Army's readiness level declined one level in readiness. The major concern was that if these declines in readiness were to become protracted, they could have resulted in lower cumulative training and thus reduced the long-term readiness. In those heavy divisions whose readiness declined as a result of cuts in training, personnel missed important training events, gunnery practice, maneuver exercises and the like. Although training funds were eventually restored, it takes time to make up for the lost training opportunities. ${ }^{24}$

Another issue is the amount of time soldiers spend away from their homebase training facilities and families. These tour lengths have important implications for readiness and quality of life. If units have only a little more than a year for a cycle of retraining to their original readiness level while maintaining skills, and then training to special deployments tasks, it seems unlikely they will have time to progress to highly integrated combined arms training. This will affect even units that are not deployed: for example, an armored brigade that has its mechanized infantry battalion deployed to an OOTW operation will not be able to train as a combined arms task force until that unit returned from deployment. With short operational deployments, the time to next deployment rapidly decreases with the fraction of the force deployed. With one-fifth of the force deployed on this or 
related operations, the time until the soldiers next deployment is 16 months (with four month operational deployments) or 24 months (with six-month operational deployments). With a third of the force deployed, the time to next deployment plummets to eight months (for four-month operational tours) or 12 months (for sixmonth operational tours). ${ }^{25}$

A worse case scenario was graphically portrayed by Air Force Colonel Charles Dunlap in Eletcher Forum of World Affairs as he described a situation where the United States Army was not prepared to fight a Major Regional Contingency and was soundly defeated on the battlefield. He claimed that the American decision to embrace non-traditional missions was a calamity. When the time came to meet a traditional military threat, too many of the soldiers had lost their military skills and their fighting spirit. Warfighting preparation became a footnote in the minds of America's defense establishment. ${ }^{26}$

\section{HOW LONG DOES IT TAKE TO RETRAIN AFTER OOTW?}

With the addition of some specialized training recent U.S. participation in peacekeeping and peace enforcement operations has led to the conclusion that well-trained units can easily transition to operations other than war. ${ }^{27}$ The issue is, how long does it take for an Army unit to return to a high state of combat readiness, capable of fighting a major regional conflict? The Canadian experience in peacekeeping operations resulted 
in its conventional combat forces requiring at least four months of training to regain their warfighting skills following a deployment. ${ }^{28}$

Army units can be expected to return to normal combat readiness four to six months after return from an extended peace operation. The principal limiting factors are maintenance, availability of training resources and substantial personnel turbulence. Light infantry and other units with very little equipment will recover faster. Vehicle intensive units that deploy their own equipment can be expected to take the longest. Many units are deployed to perform tasks that are not related to their wartime Mission Essential Task List (METL). These units may need more time to return to normal readiness. An example is the Air Defense Battalion, located with the Light Infantry Division in Fort Drum, New York, whose high density of vehicles and radios were essential for the successful performance of the units supported. During the Somalia deployment a battery deployed with an infantry brigade and performed missions such as: route security for UN food convoys, operating food distribution sites for starving Somalians, performed route patrolling missions, and conducted weapons search and seizure missions. One platoon from another battery deployed with the aviation brigade as door gunners. In Haiti a majority of the battalion deployed to perform the following missions: conduct the weapons buy-back program, provide guards for the presidential palace and other important government buildings, operated prisoner camps, 
conducted day and night route patrolling, provided communications and transportation support to infantry brigades and provided fillers for division and brigade staffs.

Regardless of type of unit or type of mission conducted all units involved in OOTW go through seven common phases while returning to normal combat readiness:
a. Initial recovery (1-2 weeks).
b. Block leave (2 weeks).
c. Maintenance (1-6 months).
d. Personnel restructuring ( 3 months).
e. Individual training (4-6 weeks).
f. Collective Training (2-10 weeks).
g. Transportation of equipment from deployment area $(1-6+$ months $) .{ }^{29}$

A worse case scenario would be to extract a unit out of a OOTW mission to fight a Major Regional Contingency in another part of the world. Timelines to reconstitution for a MRC would be as follows:

a. Combat Arms units: 30 days are the minimum required, accepting what may be serious risk. Training corners will be cut. Very difficult to include complete live-fire exercises. Deadline maintenance will be only task. 75-90 days are optimum. This provides little time for maintenance, training, and family time.

b. Combat support units: 30-45 days are the minimum. numerous vehicles are normally involved, requiring a lot of maintenance time. CS unit that are involved directly in combat 
missions will also require detailed combat training and battle drills. 60-90 days are the optimum.

c. Combat Service Support Units: 15-60 days are required. CSs units vary significantly in equipment density and mission. Normally, these units will perform their wartime mission under similar conditions in either a peace operation of an MRC. Their issue is how much maintenance is required on their equipment and will they have time for their own recovery before they have to support the recovery of other units. ${ }^{30}$

The fact is, when an Army unit returns back to home station from a peacekeeping mission, it will take a certain amount of time before that unit returns to a combat capable unit.

\section{CONCLUSION}

Although there are many positive effects Operations Other Than War (OOTW) has on the readiness of the United States Army and while some units benefit more than others, the prolonged effect could be disastrous to the Army as a whole. Combat units and some combat support units lose the opportunity to train on their warfighting skills while they are involved in peacekeeping missions. All units lose the art of training as a combined arms force in preparing for a defensive or offensive operation. The retraining time after an OOTW mission requires the Army to perform dedicated training for at least four to six months to return to a high state of combat readiness. Depending on the 
situation, they may not have that amount of time to retrain. A worse case scenario (and a likely scenario) would be to extract Army units from an OOTW role and deploy it to a MRC without giving it the opportunity to retrain to its warfighting posture. Although peacekeeping operations may be beneficial in developing Mission Essential Task Lists (METL) for many Army units, it will, over time degrade a units warfighting capabilities that will require intensive retraining to return to a highly responsive warfighting capability.

The Army's continuous involvement in peacekeeping roles become a sounding board for senior political leader who feel the Army should become more involved in solving domestic issues in our own back yard. They feel that since the Army is involved in supporting foreign countries with their internal problems, why not spend all that energy and resources on solving our own problems. Some even feel that the Army should conduct a complete restructure of its organization to better service peacekeeping and humanitarian operations. The longer the Army spends on conducting peacekeeping the more justification these senior leaders have in making the Army a peacekeeper of domestic issues. Even the Army's doctrinal writers are now focusing more on peacekeeping roles than ever before. The Army is becoming slowly immersed in peacekeeping and at the same time focusing less on its primary mission of fighting wars.

The present National Strategic Policy on Operations Other Than War commits the United States Army to a permanent peacekeeping 
role. Without a strong strategic peacekeeping policy from the National Command Authority, the Army will eventually become a professional peacekeeping Army and will lose its ability as a responsive fighting force capable of defeating an enemy in a Major Regional Conflict. 


\section{ENDNOTES}

1. FM 100-5, Operations, Headquarters, Department of the Army, June $1993, \mathrm{p} \cdot \frac{30-1 .}{3}$

2. President of the United States, A National Security Strategy of Engagement and Enlargement, The White House, February 1995, p.8.

3. Ibid., p. 12 .

4. Jandora, John W., "Threat Parameters for Operations Other Than War", Parameters, US Army War College Quarterly, Vol., XXV No. 1, Spring 1995, p.57.

5. Taw, Jennifer M. \& Leicht, Robert C., The New World order and Army Doctrine, The Doctrinal Renaissance of Operations Short of War., published by RAND institution, June 1992, p. v.

6. Nunn, Sam senator, Domestic Missions for the Armed Forces, Strategic Studies Institute, U.S. Army War College, Carlisle Barracks, PA., February 1993, pp. 1-2.

7. Ibid. p. 1 .

8. Metz, Steven, America In the Third World: Strategic Alternatives and Military Implications, Strategic Studies Institute, U.S. Army War College, Carlisle Barracks, PA., May 20, 1994. p. vi.

9. FM 100-5, Operations, Headquarters Department of the Army, June 1993. p. 30-1.

10. FM 100-23, Peace Operations, Headquarters, Department of the Army, June 1993, p. 89.

11. 10th Mountain Division (Operation Uphold Democracy) Operations in Haiti/Planning/Preparation/Execution. August 1994 to January 1995. pp. $24-2 \& 24-3$.

12. 10th Mountain Division, (Operation Uphold Democracy), Operations In Haiti/Planning/Preparation/Execution. August 1994 thru January 1995, p. 24-3.

13. Joulwan, General George A., US Army, "Operations Other Than War: A CINC's Perspective", Military Review, Volume LXXIV, February 1994, No 2. p. 10.

14. Blechman, Barry M. \& Vaccaro, Matthew J., Training for Peacekeeping: The United Nations' Role, The Henry L. Stimson Center, Washington D.C., Report No. 12, July 1994, p. 2. 
15. Schinasi, Lee D. Col, America's Unfocused Humanitarian and Civic Assistance Programs: Is Anybody in Charge? Where Are We Going, U.S. Army War College, Carlisle Barracks, PA, Class of 1993, pp. 27-28.

16. Miller, Admiral Paul D., "In the Absence of War: Employing America's Military Capabilities in the 1990s, The Fletcher Forum of World Affairs, volume 18, Number 1, Winter/Spring 1994, p. 12.

17. FM 100-23 Peace Operations, Headquarters, Department of the Army, December 1993, p.1.

18. Curtis, willie, The Inevitable slide into Coercive Peacemaking: The US Role in the New World Order, Defense Analysis, Volume 10 Number 3, December 1994, p. 313.

19. Rosenau, William, Non-Traditional Missions and the Future of The U.S. Military, Fletcher Forum of World Affairs, Vol. 8, Winter-Spring, pp. 31-48.

20. Sanford, Timothy L., other Than War Missions: What Role Should They Plan in Tomorrow's Army?, student paper files, Carlisle Barracks: U.S. Army War College, 14 April 1993, pp. $8 \& 9$.

21. Roos, Johm G. "The Perils of Peacekeeping: Tallying the costs in Blood, Coin, Prestige, and Readiness, Armed Forces Journal, December 1993, p. 16 .

22. Applegate, Melissa A., Military Power in Operations Other Than War, Fort Leavenworth, Kansas, 1994, p.16.

23. Cropsey, Seth, "The Hard Truth About Soft Missions", The Wall street Journal, Vol. CCXXI No. 12, Tuesday January 19, 1993.

24. Finch, Louis C., Deputy Under Secretary of Defense for Readiness, "Keeping Forces Ready to Fight," Defense 95, issue 4, pp. 5-10.

25. Quinlivan, James T., Eorce Requirements in Stability Operations, Parameters, Winter 1995-96, United States Army War College, Carlisle Barracks, PA, pp. 59-69.

26. Dunlap, Colonel Charales J. Jr., USAF, "The Last American Warrior, Non-traditional Missions and the Deciine of the U.S. Armed Forces, The Fletcher Forum of World Affairs, Volume 18, Number 1, Winter/Spring 1994, pp. 66-81.

27. Center For Army Lessons Learned (CALL), Bosnia Contingency Planning and Training, U.S. Army Combined Arms Center (CAC), Fort Leavenworth, Kansas, September 1994, p. iv. 
28. Applegate, Melissa A., Military Power in Operations Other Than War, Fort Leavenworth, Kansas, 1994, p. 16.

29. Center For Army Lessons Learned (CALL), Operations Other Than War Volume IV Peace Operations, U.S. Army Combined Arms Command (CAC), Fort Leavenworth, Kansas, No. 93-8, December 1993, p. $\mathrm{V}-1$.

30. Ibid. pp. 14-15. 


\section{BIBLIOGRAPHY}

1. 10th Mountain Division (Operation Uphold Democracy), operations in Haiti/Planning/Preparation/Execution. August 1994 to January 1995. pp. 24-2 \& 24-3.

2. FM 100-5, Operations, Headquarters, Department of the Army, June 1993, p. 30-1.

3. FM 100-23, Peace Operations, Headquarters, Department of the Army, June 1993, p. 89.

4. Applegate, Melissa A., Military Power in Operations Other Than War, Fort Leavenworth, Kansas, 1994, p.16.

5. Blechman, Barry M. \& Vaccaro, Matthew J., Training for Peacekeeping: The United Nationa' Role, The Henry L. Stimson Center, Washington D.C., Report No. 12, July 1994, p. 2 .

6. Center for Army Lessons Learned (CALL), Bosnia Contingency Planning and Training, U.S. Army Combined Arms Center (CAC), Fort Leavenworth, Kansas, September 1994, p. iv.

7. Center for Army Lessons Learned (CALL), Operations other Than War Volume IV Peace operations, U.S. Army Combined Arms Command (CAC), Fort Leavenworth, Kansas, No. 93-8, December 1993, p. V-1.

8. Cropsey, Seth, "The Hard Truth About Soft Missions", The Wall Street Journal, Vol, CCXXI No. 12, Tuesday January 19, 1933. pp. $24-27$.

9. Curtis, Willie, The Inevitable slide into "Coercive Peacemaking: The US Role in the New World Order, Defense Analysis, Volume 10 Number 3, December 1994, p. 313.

10. Dunlap, Colonel Charles J. Jr., USAF, "The Last American Warrior, Non-traditional Missions and the Decline of the U.S. Armed Forces", The Fletcher Forum of World Affairs, Volume 18, Number 1, Winter/Spring 1994, pp. 66-81.

11. Finch, Louis C., Deputy Under Secretary of Defense for Readiness, "Keeping Forces Ready to Fight," Defense 95, issue 4, pp. $5-10$.

12. Jandora, John W., "Threat Parameters for Operations Other Than War', Parameters, U.S. Army War College Quarterly, Vol., $\mathrm{XXV}$, No. 1, Spring 1995, p. 57. 
13. Joulwan, George A., General, United States Army, "Operations Other Than War: A CINC's Perspective", Military Review, Volume LXXIV, February 1994, No 2. p. 10.

14. Metz, Steven, America In the Third World: Strategic Alternatives and Military Implications, Strategic Studies Institute, U.S. Army War College, Carlisle Barracks, PA., May 20, 1994, p. vi.

15. Miller, Admiral Paul D., "In the Absence of War: Employing America's Military Capabilities in the 1990, The Fletcher Forum of World Affairs, volume 18, Number 1, Winter/Spring 1994, p. 12.

16. Nunn, Sam Senator, Domestic Missions for the Armed Forces, Strategic Studies Institute, U.S. Army War College, Carlisle Barracks, PA., February 1993, p. 1-2.

17. President of the United States, A National Security Strategy of Engagement and Enlargement, The White House, February 1995, p. 8 .

18. Quinlivan, James T., Force Requirements in Stability Operations, Parameters, Winter 1995-1996, United States Army War College, Carlisle Barracks, PA., pp. 59-69.

19. Roos, John G., "The Perils of Peacekeeping: Tallying the costs in Blood, Coin, Prestige, and Readiness, Armed Forces Journal, December 1993, p. 16.

20. Rosenau, William, Non-Traditional Missions and the Future of The United States Military, Fletcher Forum of World Affairs, Vol. 8, Winter-Spring, pp. 31-48.

21. Sanford, Timothy L., other Than War Missions: What Role Should They Plan in Tomorrow's Army?, student paper files, Carlisle Barracks: U.S. Army war College, 14 April 1993, pp. 8-9.

22. Schinasi, Lee D. Colonel, America's Unfocused Humanitarian and Civic Assistance Programs: Is Anybody in Charge: Where Are We Going, U.S. Army War College, Carlisle Barracks, PA., Classof 1993, pp. 27-28.

23. Taw, Jennifer M. \& Leicht Robert C., The New World Order and Army Doctrine, The Doctrinal Renaissance of Operations short of War, published by RAND Institution, June 1992, p. v. 